\title{
Impact of Intellectual Capital from Market Capitalization on Profitability in Financial Sector of Oman
}

\author{
Dr. Faris Nasif ALShubiri \\ Dhofar University, College of Commerce and Business Administration - Sultanate of Oman, \\ Email:fa_shub@yahoo.com
}

\section{Doi:10.5901/mjss.2015.v6n2p54}

\begin{abstract}
This study aims to demonstrate the impact of the intellectual capital from market capitalization on profitability in the financial sector listed in Muscat Security Market (MSM) of Oman for the period from 2009 to 2013 for 36 firms included in six sectors but the researcher taken only 32 firms because two banks in banking sector and two firms in insurance sector not have enough data for the period of study This study used market capitalization methods (MCM) to measure IC as independent variables on profitability. The results indicated a statistical significant impact of Tobin's $q$ and market to book value on profitability based on $R O E$ and EPS. The multiple regression is indicated a statistical significant impact of all impendent variables on earnings per share only. The researcher recommends to strengthening the role of the intellectual capital in financial sector as an important indicator enhances productivity, efficiency and effectiveness also firms must evaluates the intellectual capital in several methods with best selection in line with the strategy of investing in the long term.
\end{abstract}

Keywords: Intellectual Capital, Market Capitalization, Profitability.

\section{Introduction}

The use of intellectual capital (IC) includes advanced knowledge in the organization, use of intangible assets and human resources which lead to add value and gives a competitive advantage for the firms and for individuals, also there are three main elements of IC that are physical (customer), human and structural capital, first:: Human capital is the basis of intellectual production process but requires for the success of the skills and adequate training. Second: Structural capital which is about an asset exists to support the firm's production process and supports the human capital. Third: Customer capital is a regulatory process for all acts of intellectual capital converted to market value, so intellectual capital is a strategy for how intangible assets management creates a competitive advantage and is reflected in the financial performance, Pulic (2004).

Dzinkowski, (2000) define the intellectual capital as intellectual assets that enhance the growth of the firm, based on the equity firms. .Stewart (1997) noted that the intellectual capital measures were used in the current studies related to intangible assets by identifying what is the firm value of shares in the market compared to the value recorded in the balance sheet and any difference in it expresses the intangible value in the capital intellectual.

In this study will examine the impact of the IC developed from market capitalization on profitability. Market capitalization method (MCM) has a specific value, because stock prices influenced by many economic variables and the book value. These explain the historical cost not real tangible assets. The Tobin's $q$ is used to predictable investment decisions and is similar to the market to book value but the difference is the Tobin's q. used replacement cost of tangible assets rather than book value. This study explain how they impact on the financial performance since the conservative accounting practices indicate that the projects of investment based on IC provided through analysis of financial statements and due to the increase in the difference between the MV and BV, so that may be reflected on the value of the firm and thus on the IC and this process may be contribute to building the firm value and improve its financial position and earnings.

\section{Objectives of the Study}

Based on the above can explain the objectives of study first: to provide a definition of intellectual capital as a measure of intangible assets and apply it on the financial sector in the Sultanate of Oman, which is one of the important and dynamic sectors at the level of the country's economy based on the results of previous studies. Second, the diagnosis of how to 
measure the IC through the market value method based on financial measure depending on the financial statements. Third, test the impact of IC on the profitability of financial sector Fou.rth and finally, make recommendations that can enhance the reliance on the concept of intellectual capital as an indicator associated with the value of the firm.

\section{Significance of the Study}

The traditional methods of accounting systems in the measurement of capital intellectual insufficient where there must be a comprehensive measure includes all the knowledge based on internal and external firm level, because the intellectual capital has a value associated with how to identify corporate strategy over the long term through asset valuation and decision-making on this, particularly with regard to increase and diversify their products and services so as to maximize the value of assets in line with the vision of the owners, as well as in percentage enhance the competitive advantage in the market when companies are taking into account the concept of evaluation of intangible assets, which is one of the firms resources.

\section{Literature Review}

Cazavan-Jeny (2004), found that the goodwill is an example of intangible assets that explain the difference between the (MV) and (BV). Garcia-Meca and Martinez (2005) explain the financial statements of the IC through data analysis and found that the use of the intellectual capital of the firm enhances shareholder value and is one of the strategic policies.

Chen, Cheng, and Hwang, (2005) found that the R\& D has a positive on improving the efficiency of the firm performance that because the firms possess IC. Tan et al (2007) found that human capital does not include employee expenses not be counted among the input costs if this has been introduced to the concept of IC as a measure creates value to the firm.. The results of the study found a relationship between the quality of the IC and the technological process, which explains the firm's activities and modern standards, is more widely used than the traditional interpretation of standards in asset quality.

Dammak and al (2009) developed a model of the structure to measure the impact of IC which includes human and structural capital on the financial market and the results of a study of the presence of a statistically significant relationship between the intellectual capital and market value. Muhammad and Ismail (2009) found that the banking sector is more effective than the other sectors in respect of attention to the relationship between IC and performance sectors.

Kalyta (2011) found there is a relationship between the number of variables such as stock prices and the Tobin's q and increase the number of members of the board of directors as a concept reflects the intellectual capital. Hess et al. (2011) found that intangible assets as an indicator of the IC have an impact on the ability to adopt the innovation process. On the other hand, in knowledge economy firms depending more on intellectual rather than physical capital.

Janosević et al. (2013) found that the competitive advantage achieved through long-term perspective and not short-term, through taking into consideration the intellectual capital as advanced management and not traditional. Salehi, Moheb Seraj and Mohammadi (2014) found that the components of the global economy develops and moves according to the knowledge and information accumulated and that evidence of the intellectual capital in the construction of the state's economic strategies.

\section{Methodology of Study}

This study used an empirical methodology to test the hypotheses. The data collected through annul firms guide of financial sector listed of Muscat Security Market (MSM) of Oman.

Through a review of previous literature there are many different methodologies to measure intellectual capital, and these ways are : direct method, market value method, return on assets method and Scoreboard method, where the researcher using a derivative of the value of the intellectual capital through systematic market value .The indicator of market capitalization index reflect the real postion of firms in the market also received a manner that increases the reliability of this method since the creation of the value of the company depends on the resources and infrastructure owned by the tangible and intangible assets that contribute to increase cash flow and enhance the competitive advantage as this will not be achieved without exploit all resources efficiently. 


\subsection{Population of the Study}

The population is taken from 2009 -20013 of financial sector listed of Muscat Security Market in Oman for 36 firms included in six sectors but the researcher taken only 32 firms because (2) banks in banking sector and (2) firms in insurance sector not have enough data for the period of study. The sectors as the following: (6) banks in banks sector, (5) firms in insurance sector, (6) firms in finance \& leasing, sector, (12) firms in investment \& brokerage sector , (1) firm in real estate sector and finally, (2) firms in funds sector.

\subsection{Hypotheses of the Study}

Through a review of previous literature where the researcher extract variables and hypotheses of the study to measure the intellectual capital that developed through used Market Capitalization Method (MCM) as suggested by Anvari Rostami, A.A. and Seraji,H. (2005), Stewart, Th.(1997) to test the following hypotheses' statement:

Hypothesis One: There is no statistical significant impact of the MTBV on ROE in financial sector of Oman.

Hypothesis Two: There is no statistical significant impact of the MTBV on EPS in financial sector of Oman.

Hypothesis Three: There is no statistical significant impact of the TQ on ROE in financial sector of Oman.

Hypothesis Four: There is no statistical significant impact of the TQ on EPS in financial sector of Oman.

\subsection{Variables and Model Selection}

\subsubsection{Variables of Study}

The dependent variable is profitability and measure in two ways from earnings per share (EPS) and return on equity $(R O E)$. The independent variables used in this study to measures the intellectual capital from market capitalization are:

1. Tobin's q (TQ): calculated by the market value of firm dividing by total asset

2. Market-to-Book Value (MTBV): calculated by the difference between the firms's market value of stock and book value of firm dividing the average inflation rate during the (t) period.

\subsubsection{Model of Study:}

$X_{i t}=a_{0}+b_{1} T Q_{i t}+b_{2} M T B V_{i t}+\varepsilon_{i t}$

Where, $X_{\text {it }}=R O E$, EPS

\section{Empirical Results and Discussion}

Table No. 1 shows the results of the financial analysis and descriptive statistics on return on equity in each sector of financial sectors. ROE is one of independent variable measure the profitability of sector and presents six sectors (banks, insurance, finance and leasing, investment and brokerage, real estate and funds) from the period 2009 to 2013. As the result shows the largest mean of return on equity is in real estate sector because have a big number in 2013 only and the lowest mean is in finance and leasing but the largest slandered deviation is in insurance sector and the lowest is in funds sector.

Table 1: The Financial Analysis \& Descriptive Statistics of ROE in each sector:

\begin{tabular}{|l|c|c|c|c|c|c|c|}
\hline \multicolumn{7}{|c|}{ Financial Analysis } & \multicolumn{2}{c|}{ Descriptive Statistics } \\
\hline Return on Equity & 2013 & 2012 & 2011 & 2010 & 2009 & Standard Deviation & Mean \\
\hline Banks & 0.134833 & 0.131 & 0.118167 & 0.122667 & 0.102833 & 0.1219 & 0.01253 \\
\hline Insurance & 0.1 & 0.053333 & 0.033333 & 0.106667 & 0.036667 & 0.660 & 0.03499 \\
\hline Finance \& Leasing & 0.118333 & 0.113333 & 0.12 & 0.105 & 0.108333 & 0.1130 & 0.00639 \\
\hline Investment \& Brokerage & 0.06 & -0.03833 & -0.125 & 0.036667 & -0.04667 & -0.0227 & 0.07357 \\
\hline Real Estate & 0.35 & -0.01 & -0.01 & -0.02 & -0.02 & 0.0580 & 0.16331 \\
\hline Funds & 0.131667 & 0.008333 & -0.07333 & 0.018333 & 0.071667 & -0.0313 & 0.07640 \\
\hline
\end{tabular}

Table No. 2 shows the results of the financial analysis and descriptive statistics on earnings per share in each sector of 
financial sectors. EPS is another independent variable measure the profitability of sector. As the result shows the largest mean of earning per share is in real estate sector because have a big number in 2013 only and the lowest mean is in investment and brokerage sector but the largest slandered deviation is in real estate sector and the lowest is in banks sector.

Table 2: The Financial Analysis \& Descriptive Statistics of EPS in each sector:

\begin{tabular}{|l|c|c|c|c|c|c|c|}
\hline \multicolumn{7}{|c|}{ Financial Analysis } & \multicolumn{2}{c|}{ Descriptive Statistics } \\
\hline Earnings Per Share & 2013 & 2012 & 2011 & 2010 & 2009 & Standard Deviation & Mean \\
\hline Banks & 0.0342 & 0.031133 & 0.0264 & 0.027683 & 0.024983 & 0.00375 & 0.0289 \\
\hline Insurance & 0.041 & 0.002833 & 0.063333 & 0.057833 & 0.108 & 0.03809 & 0.0546 \\
\hline Finance \& Leasing & 0.018667 & 0.019 & 0.018167 & 0.017 & 0.018167 & 0.03809 & 0.0546 \\
\hline Investment \& Brokerage & 0.018167 & -0.00683 & -0.04483 & 0.03 & -0.059 & 0.03869 & -0.0125 \\
\hline Real Estate & 1.752 & -0.186 & -0.172 & -0.312 & -0.179 & 0.88034 & 1.806 \\
\hline Funds & 0.396167 & 0.010667 & -0.102 & -0.01 & 0.0795 & 0.19096 & 0.0749 \\
\hline
\end{tabular}

Table No. 3 shows the results of the financial analysis and descriptive statistics on market to book value in each sector of financial sectors. MTBV is one of dependent variable measure the intellectual capital from market capitalization. As the result shows the largest mean of MTBV is in real estate sector and the lowest mean is in banks sector but the negative largest slandered deviation is in real estate sector and the lowest is in funds sector

Table 3: The Financial Analysis \& Descriptive Statistics of MTBV in each sector:

\begin{tabular}{|l|c|c|c|c|c|c|c|}
\hline \multicolumn{7}{|c|}{ Financial Analysis } & \multicolumn{2}{c|}{ Descriptive Statistics } \\
\hline Market-to-Book Value & 2013 & 2012 & 2011 & 2010 & 2009 & Standard Deviation & Mean \\
\hline Banks & -2.30473 & -2.16739 & -2.30426 & -2.24457 & -2.46831 & -2.297 & 0.11068 \\
\hline Insurance & 4081.688 & -1.45042 & -1.34506 & -1.37963 & -1.10985 & -1.373 & 0.17263 \\
\hline Finance \& Leasing & -1.41749 & -1.47472 & -1.55307 & -1.5703 & -1.16457 & -1.436 & 0.16375 \\
\hline Investment \& Brokerage & -1.57827 & -1.41684 & -1.19548 & -1.29431 & -0.80337 & -1.257 & 0.29143 \\
\hline Real Estate & 0.041184 & -0.39523 & -9.88616 & -2.94615 & -3.08051 & -3.253 & 3.973 \\
\hline Funds & -0.00931 & 0.008288 & -1.54934 & -0.50485 & -0.49803 & -0.5106 & 0.6324 \\
\hline
\end{tabular}

Table No. 4 shows the results of the financial analysis and descriptive statistics on Tobin's $q$ in each sector of financial sectors. TQ is another dependent variable measure the intellectual capital from market capitalization .As the result shows the largest mean of Tobin's $q$ is in real estate sector and the lowest mean is in finance and leasing sector but the largest slandered deviation is in real estate sector and the lowest is in banks sector.

Table 4: The Financial Analysis \& Descriptive Statistics of TQ in each sector:

\begin{tabular}{|l|c|c|c|c|c|c|c|}
\hline \multicolumn{7}{|c|}{ Financial Analysis } & \multicolumn{2}{c|}{ Descriptive Statistics } \\
\hline Tobin's q & 2013 & 2012 & 2011 & 2010 & 2009 & Standard Deviation & Mean \\
\hline Banks & 0.151233 & 0.148783 & 0.20791 & 0.252352 & 0.229846 & 0.1980 & 0.04659 \\
\hline Insurance & 0.353832 & 0.319597 & 0.245946 & 0.2754 & 0.448345 & 0.3286 & 0.07861 \\
\hline Finance \& Leasing & 0.313169 & 0.319908 & 0.298794 & 0.291856 & 0.325134 & 0.3098 & 0.01407 \\
\hline Investment \& Brokerage & 1.4952 & 0.933047 & 0.68842 & 0.983583 & 1.341885 & 1.0884 & 0.32590 \\
\hline Real Estate & 7.853578 & 7.481117 & 2.440187 & 3.702486 & 3.652524 & 5.0260 & 2.467 \\
\hline Funds & 1.617091 & 1.641281 & 0.7005 & 0.900308 & 0.890329 & 1.1499 & 0.4447 \\
\hline
\end{tabular}

Table No. 5 used regression test to analysis the impact of two independent variables measured the intellectual capital from market capitalization on profitability based on earnings per share listed in financial sector on Muscat Security Market. The results of the study shows the impact statistically significant for both variables Tobin's q and Market-to-Book Value at the significant level $5 \%, 10 \%$ respectively, where the value $t=2.539$ and 1.831 respectively as was the correlation coefficient 0.433 and 0.327 while the coefficient of determination was 0.187 and 0.107 which is explained by amount of the dependent variable. 
Table 5: Regression Analysis of independent Variables (TQ, MTBV) \& Dependent Variable EPS

\begin{tabular}{|l|c|c|c|c|}
\hline Independent Variables & $\mathrm{R}$ & $\mathrm{R}^{2}$ & $\mathrm{~T}$ - Value & $\mathrm{Sig}$ \\
\hline Tobin's q & 0.433 & 0.187 & 2.539 & $0.017^{\star \star}$ \\
\hline Market-to-Book Value & 0.327 & 0.107 & 1.831 & $0.078^{\star}$ \\
\hline
\end{tabular}

*Sig at $p<0.10^{* \star}$ Sig at $p<0.05^{* \star *}$ Sig at $p<0.01$

Table No. 6 used regression test to analysis the impact of two independent variables measured the intellectual capital from market capitalization on profitability based on return on equity listed in financial sector on Muscat Security Market. The results of the study shows the impact statistically significant for both variables Tobin's $q$ and Market-to-Book Value at the significant level $1 \%, 5 \%$ respectively where the value $t=3.017$ and -2.476 respectively as was the correlation coefficient 0.495 and 0.424 while the coefficient of determination was 0.245 and 0.180 which is explained by amount of the dependent variable.

Table 6: Regression Analysis of independent Variables (TQ, MTBV) \& Dependent Variable ROE

\begin{tabular}{|l|c|c|c|c|}
\hline Independent Variables & $\mathrm{R}$ & $\mathrm{R}^{2}$ & $\mathrm{~T}$ - Value & Sig \\
\hline Tobin's q & 0.495 & 0.245 & 3.017 & $0.005^{\star \star \star}$ \\
\hline Market-to-Book Value & 0.424 & 0.180 & -2.476 & $0.020^{\star \star}$ \\
\hline
\end{tabular}

*Sig at $p<0.10$ ** Sig at $p<0.05^{* * \star}$ Sig at $p<0.01$

Table No. 7 used multiple regression tests to investigate the impact of all impendent variables on profitability. The results of the study shows the impact statistically significant for all impendent variables and earnings per share at the significant level $5 \%$, where the value $F=5.339$. But there is no statistical significant impact of all impendent variables on return on equity.

Table 7: Multiple Regression Analysis of all independent Variables \& Each Dependent Variable

\begin{tabular}{|l|c|c|}
\hline Dependent Variables & F- Value & Sig \\
\hline Return on Equity & 0.673 & 0.518 \\
\hline Earnings Per Share & 5.339 & $0.011^{* *}$ \\
\hline
\end{tabular}

*Sig at $p<0.10 * *$ Sig at $p<0.05 * \star$ Sig at $p<0.01$

As the results shows, so I can discuss these numbers as the following:

Ortiz, (2006) pointed if Tobin's q greater than 1 the firm has the ability to increase profits compare with competitors in the same industrial , so the firm owns intellectual capital with competitive advantage, which adds to the firm value in the market.

The financial sector is one of the important sectors in the Sultanate of Oman, where the sector included six subsectors as the following (banks, insurance, finance and leasing, investment and brokerage , real estate and funds) where the sector contributes to the economic and financial balance and support the developmental movement in the Oman.

It also this sector contributes to supporting small and medium businesses and create jobs and reduce unemployment as the systems, procedures and laws that have been introduced to enhance confidence in the financial and banking system of Oman and enable customers to get excellent services contributed to, and within the controls and legal restrictions occasion included directing investments to sectors that State seeks to diversify and increase their role in the national economy. Omani banking sector offers a prominent and important role at the level of the economy that when you enter the Sultanate in the World Trade Organization, and require many changes and developments on the local and international level, which led to increasing the efficiency and stability of the banking system of Oman. The insurance rates imposed by the market according to factors and numerous conditions, including service cost and prices of spare parts, which makes it difficult to control, especially in light of the increasing incidents, noting that there are a number of working in the insurance companies allows for the customer to appropriate choice with the presence of competition among .

Recently the insurance firms have been linked on Royal Oman Police on the other hand to achieve some of the goals. Omani real estate market, which has seen relatively slower growth in 2011, while at the moment signs of steady growth among the factors that lie behind this positive trend will finance the construction of houses improved along with the growth of the economy. 
In genera the Omani goverment is also increases the large-scale salaries in 2011, a factor additional important behind strengthening the real estate market conditions. It also has achieved good growth in 2005 that he had received a blow after three years due to the global credit crunch. However, Sultanate of Oman able to avoiding dramatic deterioration witnessed by other gulf markets, primarily due to the relatively slow movement of construction conditions, but what is most important that the drug industry recovered quickly as it seems, in fact, the real estate prices in the Sultanate has increased three times from the level before the slowdown in the world economy.

The step taken by the Coordination Council recently pumped (50) million R.O to support transactions Muscat Securities Market (MSM), which is an important step to activate trade movement MSM through the provision of good financial liquidity by moving the investment market process. The government is making sustained and continuous efforts with regard to providing the right climate for investment in the Muscat Securities Market, or by supporting the economic sectors by giving all the facilities and privileges that support this sector and give it a chance to prove its existence to turn contribute to the economic development of the movement and to achieve the future vision of the Omani economy 2020. Despite the recent decline witnessed in the Muscat Securities Market, but the market still has good strength that enabled him to be one of the promising markets of excellence in the Middle East due to its flexible laws of local and good foreign investments Also, the private sector contributed to the construction of the economic development of the Sultanate of process and open the doors of investment to foreign entities to enhance their role and keep pace with economic and social development in the country, adding that the government had purchased some shares of good companies .

Also, the decision merger general of brokerage firms, as well as set minimum capital of these companies that the capital of no less than 5 Real million, where is its importance in supporting these companies and increase the strength of its financial position to play a more positive and effective role of both Besides strengthening market transactions or boost the national economy, especially after the Sultanate's accession to the world trade organization, which requires our companies Omani that the importance of the big international companies to face competition realize this just is not only to brokerage firms, but must be on other economic sectors multiple kinds to consider the importance of integration to face the global competition .

As the laws with respect to public shareholding companies and brokerage firms through the organization of work and a good choice for the board of directors and the development of statistical releases its own and announced in addition to other aspects will contribute to increasing investor confidence in the market. The Sultanate of Oman established investment funds in order to invest in real estate projects and develop non-traditional ways and the development of tourism projects and the management and maintenance of real estate with other parties in the establishment of funds and real estate portfolios in order to get a share of the market and take advantage of investment opportunities to achieve the best for investors returns.

\section{Conclusion and Recommendations}

The intellectual capital is one of the tools that contribute to enhancing the value of the firm and measure the effectiveness, which gives the firm a competitive advantage in the market and enhances performance as the intellectual capital is a measure of knowledge economic, so it must be enough a corporate awareness about the urban intellectual capital which is key to the success of firms in the market and growth economic indicator in the country.

The results of this study show that is a statistical significant impact of each of independent variables (TQ\& MTBV) on EPS and ROE as profitability index. But when used multiple regression tests the results show there is a statistical significant impact of all independent variables and earnings per share only. The researcher recommends to strengthening the role of the intellectual capital in firms as an important indicator enhances productivity, efficiency and effectiveness, and have different methods of firms to measuring the intellectual capital and adopt what fits with its strategy, also investor must removes fear factor and seriously considers investing in the Muscat Securities Market in accordance with specific frameworks and study-conscious firms that want to invest in them and not be the only goal of the investment is speculation only, but the investor should focus on long-term investments to have more benefit.

\section{References}

Anvari Rostami, A.A. and Seraji,H. (2005). Valuing Intellectual Capital (IC) and studying the relationship between firms IC values with their share market prices: An empirical evidence from the Tehran Stock Exchange (TSE). The Iranian Accounting and Auditing Review, No39, 49-62.

Cazavan. A, (2004), Le ratio market-to-book et la reconnaissance des immatériels - Une étude du marché français, Comptabilité Contrôle Audit, Tome 10, Vol. 2, décembre 
Chen.M , S. Cheng and Y.Hwang, (2005), An empirical investigation of the relationship between intellectual capital and firms' market value and performance, Journal of intellectual capital, pp159-176

Dammak. S, M. Triki and Y. Boujelbene, (2009), Offre volontaire d'informations sur le capital intellectuel et marché financier, Acte publié dans La place de la dimension européenne dans la Comptabilité Contrôle Audit, Strasbourg: France.

Dzinkowski, R. (2000), 'The Measurement and Management of Intellectual Capital: An Introduction', Management Accounting 77, $32-36$.

García-Meca, E, (2005), « Bridging the gap between disclosure and use of intellectual capital information », Journal of Intellectual Capital, Vol. $6, n^{\circ} .3$, p. 427

Hess AM and Rothaermel FT (2011) "When are assets complementary? Star Scientists strategic alliances and innovation in the pharmaceutical industry, Strategic Manage J. Issue 2 895-909

Janosević S., Dzenopoljac V. \& Bontis N. (2013). Intellectual Capital and Financial Performance in Serbia. Knowledge and Process Management, $20(1), 1-11$

Kalyta, Paul, (2011). Intellectual Capital, Corporate Governance, and Firm value.Retrieved from http://www.ssrn.com

Muhammad, N.M.N. and Ismail, M.K.A. (2009). Intellectual capital efficiency and firms' performance: study on Malaysian financial sectors. International Journal of Economics and Finance, 1(2), 206-12

Pulic, A. (2004), «Intellectual capital - does it create or destroy value? », Measuring Business Excellence, 8(1), 62-68

Salehi, M., Moheb Seraj, A., \& Mohammadi, R. (2014). The Effect of Intellectual Capital on the Profitability Ratios in the Banking Industry: Evidence from Iran. IUP Journal of Bank Management, 13(1), 38-52

Stewart, Th.(1997).Intellectual capitalthe new wealth of organizations, New York,N.Y:Doubleday

Tan,H.P., Plowman,D. and Hancock,P .(2007).Intellectual Capital and Financial Returns of Companies. Journal of Intellectual Capital, Vol.8, No.1, 76-95 